\title{
Influence of sintering temperature and aging on properties of cermet Ni/8YSZ materials obtained by citric method
}

\author{
Ewa Drożdż • Jan Wyrwa • Mieczysław Rękas
}

Received: 6 January 2013 /Revised: 29 March 2013 / Accepted: 6 May 2013 / Published online: 23 May 2013

(C) The Author(s) 2013. This article is published with open access at Springerlink.com

\begin{abstract}
The anode supported cell for solid oxide fuel cell, as a modification of the traditional Ni-YSZ anode supported on electrolyte, is examined in this work. The materials obtained on the base of citric method are presented and investigated in this work. The materials consisted of 40 wt.\% Ni/YSZ, 50 wt.\% Ni/YSZ and 60 wt.\% Ni/YSZ were obtained. The base Ni/YSZ materials are tested on the two ways: (a) aging tests and (b) sintering tests. All the materials after aging and sintering are tested by the impedance spectroscopy. The results of electrical conductivity for samples before and after aging show that only in the case of $40 \mathrm{wt} . \%$ $\mathrm{Ni} / \mathrm{YSZ}$, sample loses of metallic conductivity after $500 \mathrm{~h}$ of heating. The other samples reveal metallic conductivity even after long period of aging. The tests of sintering temperature show that this process does not affect significantly on electrical conductivity of the materials.
\end{abstract}

Keywords Cermet materials $\cdot$ SOFCs $\cdot$ Nickel-zirconia anode $\cdot$ Electrical properties $\cdot$ Microstructure

\section{Introduction}

Anode supported cell for solid oxide fuel cell (SOFC) has been extensively studied for about 10 years [1-3]. Such cell uses Ni/YSZ (nickel-yttria-stabilized zirconia) cermet as an anode material. The main advantages of the Ni/YSZ cermet are high mixed electronic-ionic conductivity, good catalytic activity with respect to hydrogen oxidation, high mechanical

E. Drożdż $(\bowtie) \cdot J$. Wyrwa $\cdot$ M. Rękas

Faculty of Materials Science and Ceramics, AGH University

of Science and Technology, al. A. Mickiewicza 30,

30-059 Krakow, Poland

e-mail: edrozdz@agh.edu.pl strength and relatively low price. What is more, a very important for long-life of anode is its thermal stability. Traditionally, this material is prepared by mechanical mixing of appropriate amounts of nickel or NiO with YSZ. Nowadays, the methods of wet chemical synthesis are often used in order to obtain homogenous and nanosize particles. Some original methods of synthesis described in literature are co-precipitation by $\mathrm{NaOH}$ method [4], nitrates combustion [5], combustion citrate-nitrate method [6], classical Pechini method [7], combustion of nitrate-glycine gel [8], sol-gel method with sucrose and pectin addition [9], complex-gel conversion process by EDTA [10], selfassembled NiO-YSZ directionally solidified eutectics method [11] and precipitation of $\mathrm{NiO}$ or $\mathrm{Ni}$ precursors on $\mathrm{YSZ}$ $[12,13]$. The characteristic feature of these methods is that synthesized materials have uniform nanostructure and high level porosity without a necessity of using a pore former.

The research carried out up to now proves that microstructure of materials strongly depends on particular preparation method. What is more important, microstructure of cermets affects mechanical and electrical properties of material $[4,14,15]$. The fundamental requirement for microstructure of anode materials is the continuity of phases and appropriate length of triple phase boundary (TPB). The first one ensures metallic as well as ionic conductivity, while the second is responsible for catalytic activity with respect to anode electrochemical reactions. As an example of a co-precipitation method, Sato et al. [4] showed that changes in synthesis conditions have strong influence on anode's performance. Pratihar et al. [14] showed that electrical conductivity of $\mathrm{Ni} / \mathrm{YSZ}$ cermet materials increases with decreasing level of samples porosity and investigated how an addition of pore former can influence material's conductivity. Some authors reported microstructure evolution $\mathrm{Ni} / \mathrm{YSZ}$ cermet materials under cell operation 
temperature. Marinsek and Zupan [6] showed that during the reduction of $\mathrm{NiO}$ to metallic nickel, mean particle size is growing but sintering temperature above $1,200{ }^{\circ} \mathrm{C}$ did not significantly influence the density of the material. Kim et al. [7] tested conductivity of the material (41\% porosity and $50 \mathrm{vol} \%$ of Ni/8YSZ) after heat treatment in hydrogen at $1,000{ }^{\circ} \mathrm{C}$ for $100 \mathrm{~h}$. They observed that there was no change in the conductivity after heating. They also reported a change in the thermal expansion coefficient (TEC) in the temperature range $300-1,000{ }^{\circ} \mathrm{C}$ for samples with different porosity level $(23,34$ and $41 \%)$. All samples showed similar values of TEC at $1,000{ }^{\circ} \mathrm{C}$, which indicates that TEC was independent of the porosity. Radovic et al. [16] obtained similar results. Up to now, the thermal durability was mostly examined for classically prepared anodes (with $\mathrm{NiO}$ and YSZ powders) [7, 17-21]. Only a few papers concern with a durability of materials obtained in other ways $[6,7,11,22]$. Hattori et al. [22] investigated electrical conductivity of pure YSZ (8.0-10.0 mol\% $\mathrm{Y}_{2} \mathrm{O}_{3}$ ) with annealing at $1,000{ }^{\circ} \mathrm{C}$. They showed that only materials $9.5 \mathrm{YSZ}$ and $10 \mathrm{YSZ}$ reveal no conductivity decrease after annealing (even for $1,000 \mathrm{~h}$ ). In the case of $8.0 \mathrm{YSZ}$ and $8.5 \mathrm{YSZ}$ materials, conductivity significantly decreased with time although initial conductivities for these samples were the highest from the all. The others consider influence of annealing on Ni/YSZ cermet. Kim et al. [7] examined a material obtained by precipitation of nickel by Pechini method on the YSZ surface. Their thermal/redox tests consisted in oxidation (under air atmosphere) and reduction (under hydrogen atmosphere) of samples at $800{ }^{\circ} \mathrm{C}$. The authors claim that their composite material has excellent tolerance against thermal and redox cycling in comparison to mechanically mixed $\mathrm{NiO}$ and YSZ powders. They presented microstructure changes (on the base of SEM images) of Ni/YSZ materials which confirmed nickel coarsening in the case of material made from $\mathrm{NiO} / \mathrm{YSZ}$ mixing powder and much smaller coarsening effect for $\mathrm{NiO} / \mathrm{YSZ}$ composite material. The interesting results obtained Laguana-Bercero et al. [11] for materials with channelled microstructure. They examined $\mathrm{Ni} / \mathrm{YSZ}$ sample after $300 \mathrm{~h}$ of aging in the $\mathrm{H}_{2} / \mathrm{N}_{2}$ atmosphere at $900{ }^{\circ} \mathrm{C}$. The authors found that the same samples before and after aging showed no signs of degradation in respect of porosity and electronic conductivity of material. The channelled Ni/YSZ cermet is potentially an excellent candidate for anode material in SOFC, but the method of its synthesis is complicated in comparison to the other methods. In this paper, we studied the effect of the sintering temperature and aging processes on structural and electrical properties of Ni/8YSZ cermet SOFC anode materials obtained by citric method.

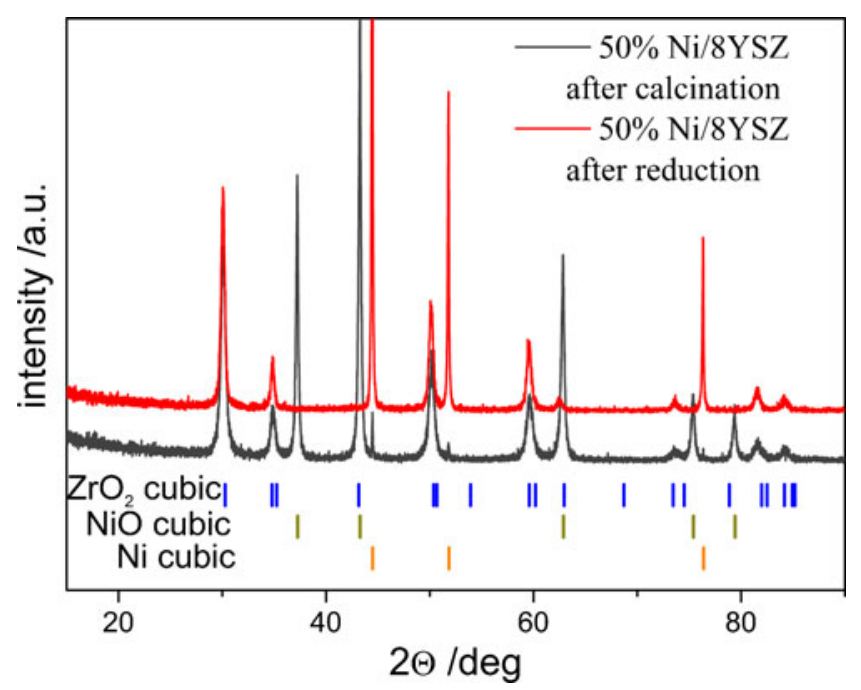

Fig. 1 XRD pattern of initial powder after calcination and after reduction

\section{Experimental}

Preparation of materials

\section{Synthesis of initial material}

Solutions of nickel, yttrium and zirconyl nitrates were prepared and mixed in proper ratio in order to obtain $\mathrm{Ni} / 8 Y S Z$. The cermet materials containing 40,50 and 60 wt. $\% \mathrm{Ni}$ in the mixture with $8 \mathrm{YSZ}(8 \mathrm{~mol} \%$ yttria$92 \mathrm{~mol} \%$ zirconia) were manufactured in this way. An appropriate amount of citric acid monohydrate (the molar ratio of fuel to nitrate was 1:1 with c.a. of $5 \%$ excess of acid) was added to metal nitrates solution. The mixed solution was put in open glass beaker and stirred for a few hours on a hot plate (around $220{ }^{\circ} \mathrm{C}$ ). Afterwards, the solution turned into grey-green gel. This gel was heated on the burner in air. Then the disk pallets were pressed and sintered at $800{ }^{\circ} \mathrm{C}$ in $10 \%$ $\mathrm{H}_{2} / 90 \%$ Ar mixture for $3 \mathrm{~h}$.

After characterisation of structural, microstructural and electrical properties of the initial materials, they were subjected additionally to aging and sintering tests.

Table 1 The total and open porosity for initial samples

\begin{tabular}{lll}
\hline Composition Ni (wt.\%) & \multicolumn{2}{l}{ Porosity } \\
\cline { 2 - 3 } & Total (\%) & Open (\%) \\
\hline 40 & $62 \pm 1$ & $53.4 \pm 0.5$ \\
50 & $67 \pm 1$ & $62.1 \pm 0.7$ \\
60 & $66 \pm 1$ & $62.3 \pm 0.9$ \\
\hline
\end{tabular}


The aging tests consist of heating the cermet pallets at $800{ }^{\circ} \mathrm{C}$ in the flow of $10 \% \mathrm{H}_{2} / 90 \% \mathrm{Ar}$ mixture for $200 \mathrm{~h}$. After this time, the pallets were sampled for SEM and electric measurements. The rest of the pallets were left in heater up to $500 \mathrm{~h}$, and after this time, they were also tested in the same way. The sintering tests relied on sintering of samples in the flow of synthetic air during $6 \mathrm{~h}$ at various temperatures within the range $800-1,300{ }^{\circ} \mathrm{C}$. Next, the samples were reduced at $800{ }^{\circ} \mathrm{C}$ in the mixture $10 \% \mathrm{H}_{2}+90 \%$ Ar for $2 \mathrm{~h}$. All samples were tested by the impedance spectroscopy after sintering, and total porosity was determined from geometrical density measurements of the pallets.
Characterisation of samples

The phase composition of the powders was determined by XRD analysis using $\mathrm{Cu}_{\mathrm{Ka}}$ radiation within $2 \Theta$ range $20-90^{\circ}$ by means of Philips X'Pert Pro diffractometer. The SEM observations were done using JROL 5400 scanning electron microscope with EDS analyser.

The open porosity was calculated using water saturation method. The total porosity was determined by relative geometrical density measurements assuming that densities of metallic $\mathrm{Ni}$ and $3 \mathrm{YSZ}$ are equal to 8.908 and $6.06 \mathrm{~g} / \mathrm{cm}^{3}$, respectively.

Values of TEC measurements were determined using measuring instrument and "size changing" transducer
Fig. 2 SEM micrographs of fractures of initial and after aging for $500 \mathrm{~h}$ materials: $40 \%$ $\mathrm{Ni} / 8 \mathrm{YSZ}(\mathbf{a}, \mathbf{b}), 50 \% \mathrm{Ni} / 8 \mathrm{YSZ}$ (c, d), $60 \% \mathrm{Ni} / 8 \mathrm{YSZ}(\mathbf{e}, \mathbf{f})$ initial materials
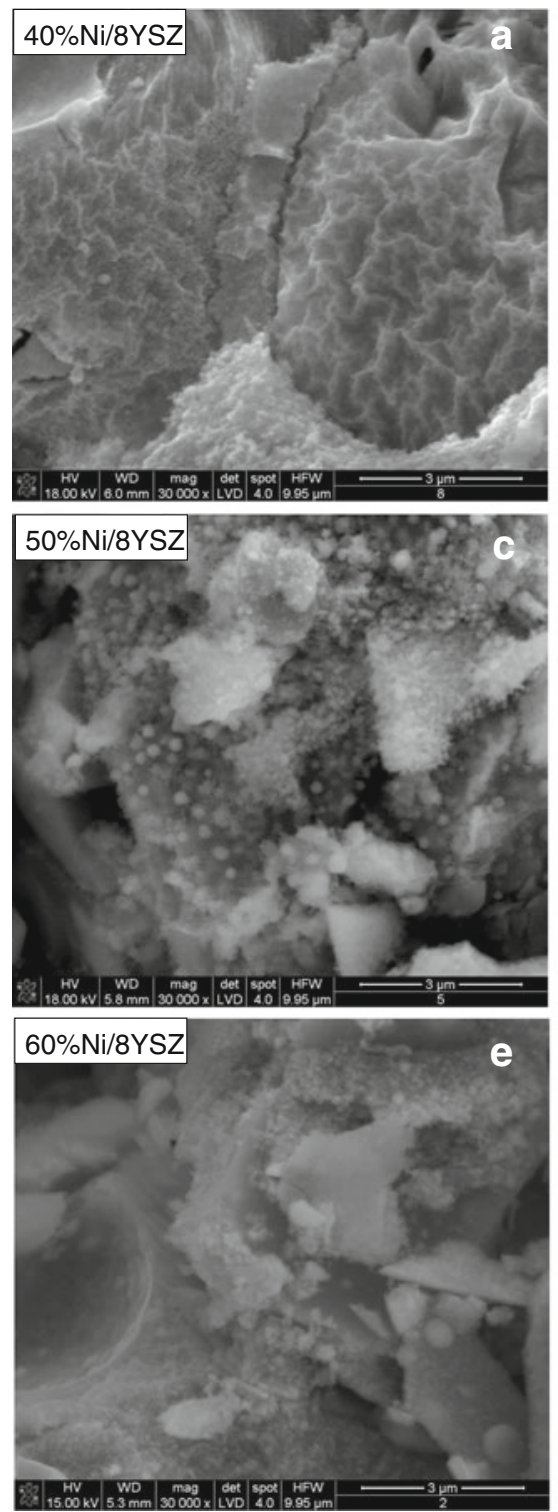

after aging for $500 \mathrm{~h}$
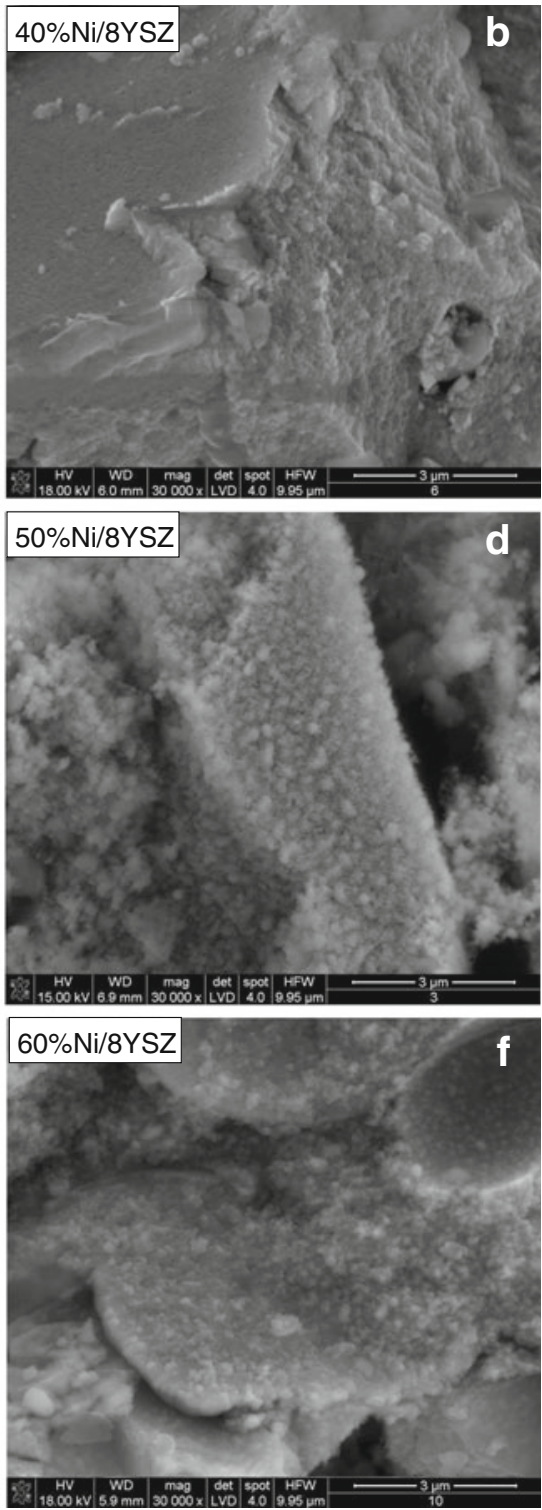
Fig. 3 Dilatometric plots for initial samples $40 \% \mathrm{Ni} / \mathrm{YSZ}$, $50 \% \mathrm{Ni} / \mathrm{YSZ}$ and $60 \% \mathrm{Ni} / \mathrm{YSZ}$

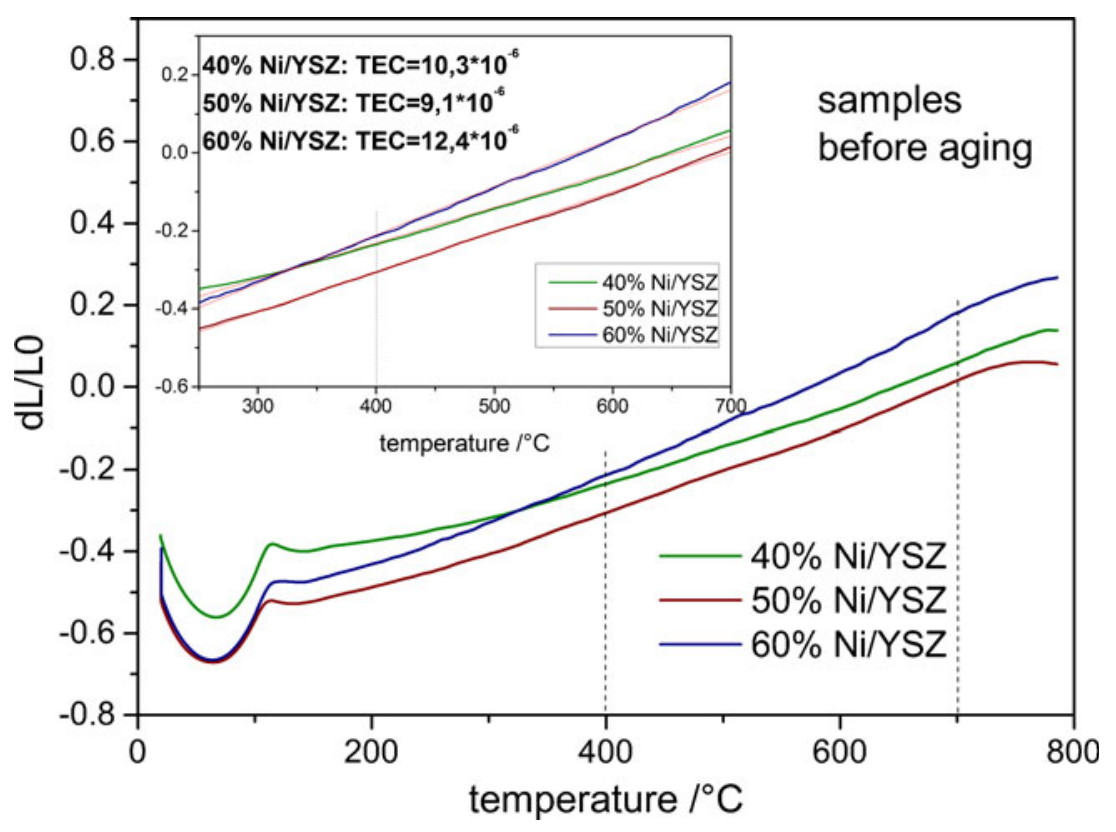

provided by a DIL $402 \mathrm{C}$ equipment from NETZSCH. Cylindrical samples of diameter $10 \mathrm{~mm}$ and thickness of $1 \mathrm{~mm}$ were used in the experiments. The measurements were performed in the Ar atmosphere containing $5 \% \mathrm{H}_{2}$; a rate of temperature change was $5{ }^{\circ} \mathrm{C} / \mathrm{min}$ within the temperature range of $20-800{ }^{\circ} \mathrm{C}$. The values of TEC were calculated using the linear regression approximation.

The electric properties measurements were carried out with Solatron SI 1260 Impedance/Gain-Phase Analyzer with the SI 1296 dielectric interface for temperature range between 20 and $700{ }^{\circ} \mathrm{C}$ at the frequencies ranging from 0.1 to $10^{6} \mathrm{~Hz}$. A flowing gas atmosphere of $10 \% \mathrm{H}_{2}$ in Ar was used.

\section{Results and discussions}

Characterisation of the initial cermet material

The X-ray analysis showed that for all compositions studied, the $\mathrm{Ni} / 8 \mathrm{YSZ}$ powders after calcination consisted only of cubic phase $\mathrm{ZrO}_{2}$ and cubic nickel oxide. After heating in $10 \% \mathrm{H}_{2} / 90 \%$ air mixture, $\mathrm{NiO}$ reduces to metallic nickel. The example of X-ray diffraction patterns for $50 \% \mathrm{Ni} / 8 \mathrm{YSZ}$ powder after calcination and after reduction is shown in Fig. 1.

The crystallite size of powders after calcination determined from the cubic $\mathrm{ZrO}_{2}$ (111) and cubic $\mathrm{NiO}(002)$ peaks broadening was equal to $15.8 \pm 0.5$ and $38.0 \pm 0.5 \mathrm{~nm}$, respectively. The crystallite sizes after reduction of the samples were $22.5 \pm$ $0.5 \mathrm{~nm}$ for $\mathrm{ZrO}_{2}$ (111) and $145.0 \pm 0.5 \mathrm{~nm}$ for cubic $\mathrm{Ni}$ (111). A significant difference in crystallite sizes of $\mathrm{NiO}$ and $\mathrm{Ni}$ confirms that the cermet heating in reducing atmosphere leads to growth of nickel crystallites. This effect is consequently connected with the TPB reduction. Marinsek and Zupan [6] in a paper mentioned above explained an effect of excessive grain growth of nickel particles as a consequence of different surface energies of nickel and YSZ resulting in poor adhesion of metallic nickel to the zirconia.

The results of total and open porosity measurements after reduction of samples (in mixture $10 \% \mathrm{H}_{2}$ in $\mathrm{Ar}$ ) are shown in Table 1. The values of total porosity calculated from the geometrical density fit in the range of $62-67 \%$. The open porosity is about $10-13 \%$ lower. All values are suitable for SOFC anode. It is significant that high degree of porosity was reached without the application of any pore formers.

SEM micrographs (Fig. 2) show that the initial samples with various content of nickel contain nano-sized crystallites. Moreover, crystallites derived from two phases, namely nickel and zircon oxide, cannot be distinguished (but they create common aggregates).

Table 2 The TEC for initial sample and for samples after aging for $500 \mathrm{~h}$

\begin{tabular}{lll}
\hline $\begin{array}{l}\text { Composition } \\
\text { Ni (wt.\%) }\end{array}$ & TEC for initial samples & $\begin{array}{l}\text { TEC for samples } \\
\text { after 500 h of heating }\end{array}$ \\
\hline Porous 8YSZ & $(8.7 \pm 0.1) \times 10^{-6}$ & - \\
$40 \% \mathrm{Ni} / 8 \mathrm{YSZ}$ & $(10.3 \pm 0.3) \times 10^{-6}$ & $(14.7 \pm 0.1) \times 10^{-7}$ \\
$50 \% \mathrm{Ni} / 8 \mathrm{YSZ}$ & $(9.1 \pm 0.1) \times 10^{-6}$ & $(15.8 \pm 0.1) \times 10^{-7}$ \\
$60 \% \mathrm{Ni} / 8 \mathrm{YSZ}$ & $(12.4 \pm 0.5) \times 10^{-6}$ & $(14.9 \pm 0.1) \times 10^{-7}$ \\
\hline
\end{tabular}


Fig. 4 Dilatometric plots for samples $40 \% \mathrm{Ni} / \mathrm{YSZ}, 50 \%$ $\mathrm{Ni} / \mathrm{YSZ}$ and $60 \% \mathrm{Ni} / \mathrm{YSZ}$ after $500 \mathrm{~h}$ aging

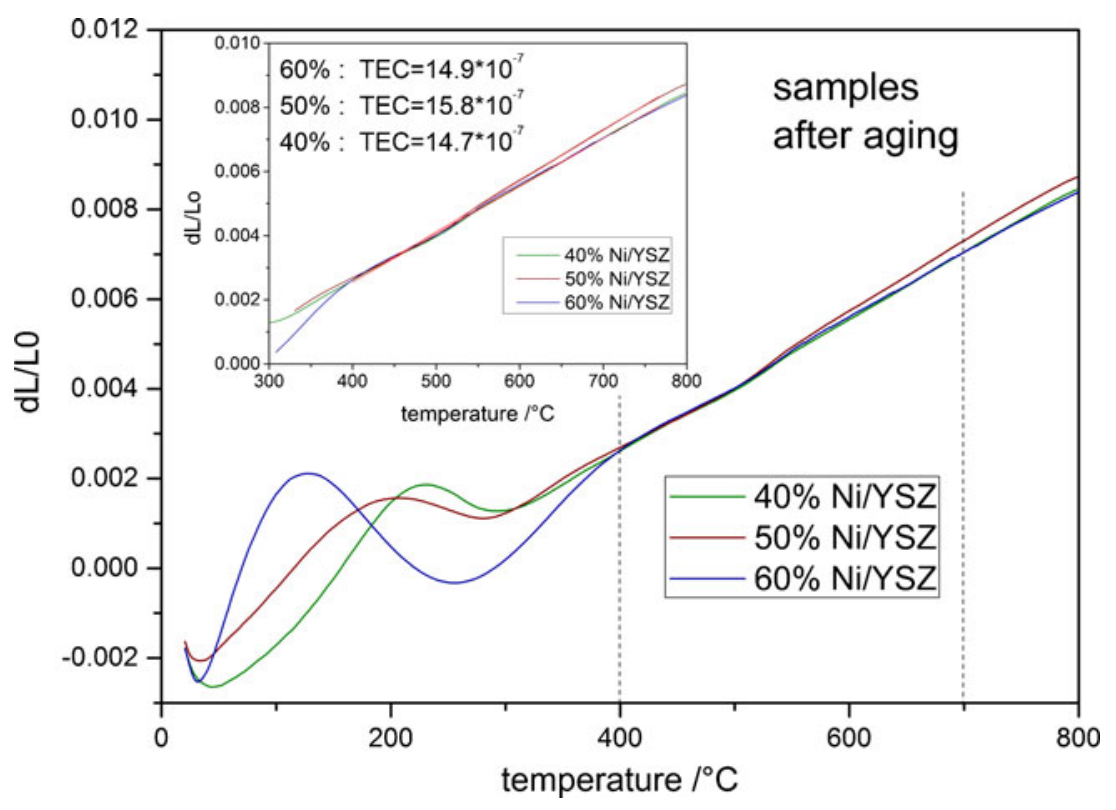

The results of dilatometric studies within temperature range of $20-800{ }^{\circ} \mathrm{C}$ are presented in Fig. 3. The thermal expansion coefficient was determined in the temperature range $400-700{ }^{\circ} \mathrm{C}$, where linear dependence of length vs. temperature $T$ can be observed. The literature TEC values for pure nickel and fully dense $8 \mathrm{YSZ}$ are $17.0 \times 10^{-6} \mathrm{~K}^{-1}$ [23] and $11.0 \times 10^{-6} \mathrm{~K}^{-1}$, respectively [24]. An analogous measurement of TEC was carried out for porous 8YSZ prepared by the same citric method. The value of TEC for this material is equal to $8.7 \times 10^{-6} \mathrm{~K}^{-1}$. TEC values of tested samples are presented in Table 2 . These values are similar to each other and fall between the TEC value of fully dense $8 \mathrm{YSZ}$ and for porous $8 \mathrm{YSZ}$, which confirms the compatibility between anode and the electrolyte materials.

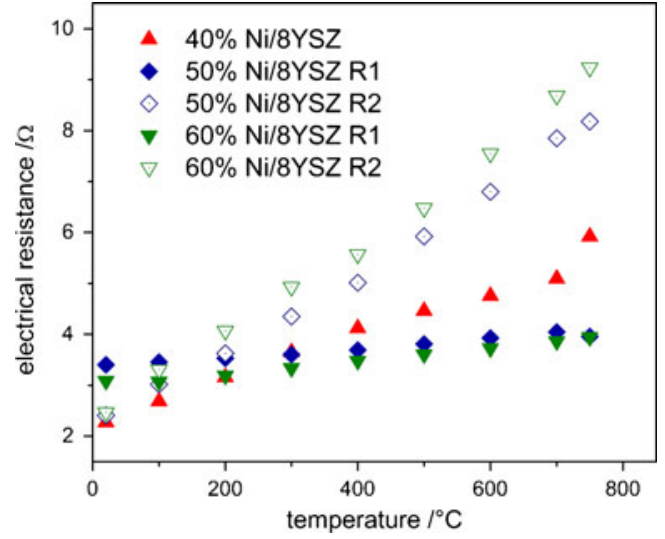

Fig. 5 Electrical resistance of all initial samples vs. temperature
Materials after aging tests

Microstructures of the cermet samples after $500 \mathrm{~h}$ of heating at $800{ }^{\circ} \mathrm{C}$ in $\mathrm{H}_{2} /$ Ar mixture are presented in Fig. $2 \mathrm{~b}$, d, f. One can observed that obtained materials have nanometric sizes before and after aging and that after long sintering the samples are more solid than initial ones. As in the case of images presented by Laguana-Bercero et al. [11] (the same blow-up), it is difficult to find in Fig. 2 any signs of degradation of cermets examined in this paper. SEM images shown by Kim et al. [7] had different enlargement (ten times) than in our studies, but it can be noticed that microstructure of their materials is similar to ours samples. a

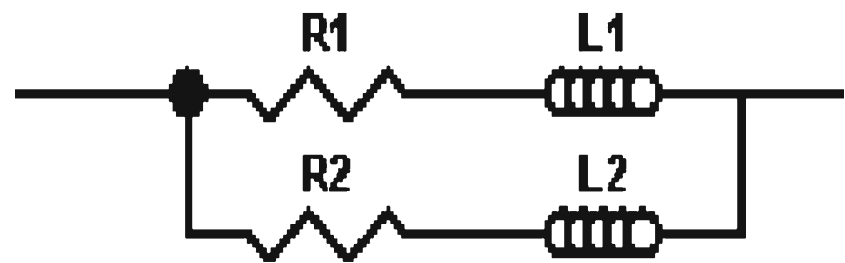

b

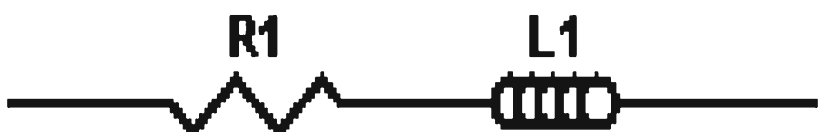

Fig. 6 Equivalent circuits used for interpretation of the impedance spectra 
Fig. 7 Nyquist plots for initial materials: $40 \% \mathrm{Ni} / \mathrm{YSZ}$ (a), $50 \% \mathrm{Ni} / Y S Z$ (b), $60 \% \mathrm{Ni} / \mathrm{YSZ}$ (c). EIS measurements performed in the $10 \% \mathrm{H}_{2} / \mathrm{Ar}$ atmosphere
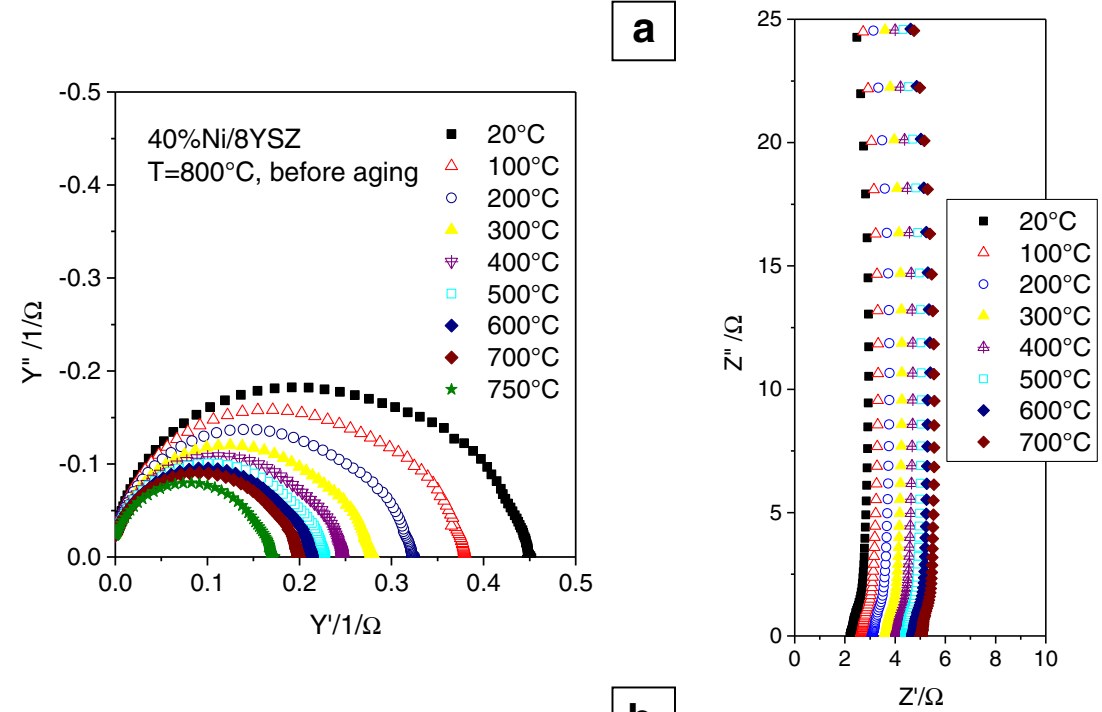

b
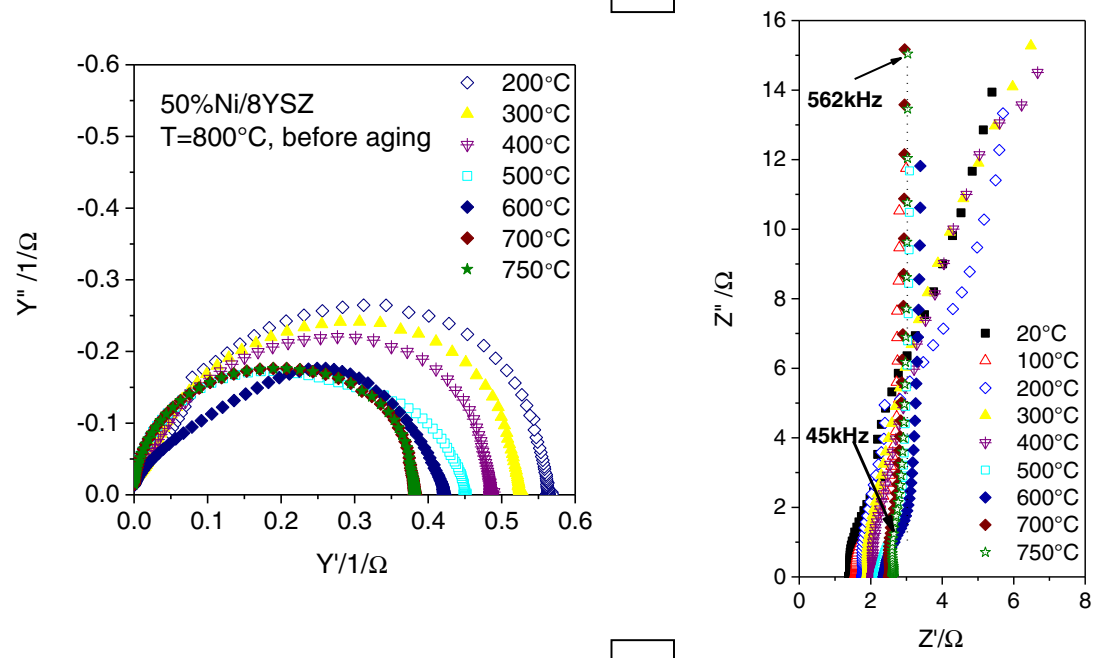

C
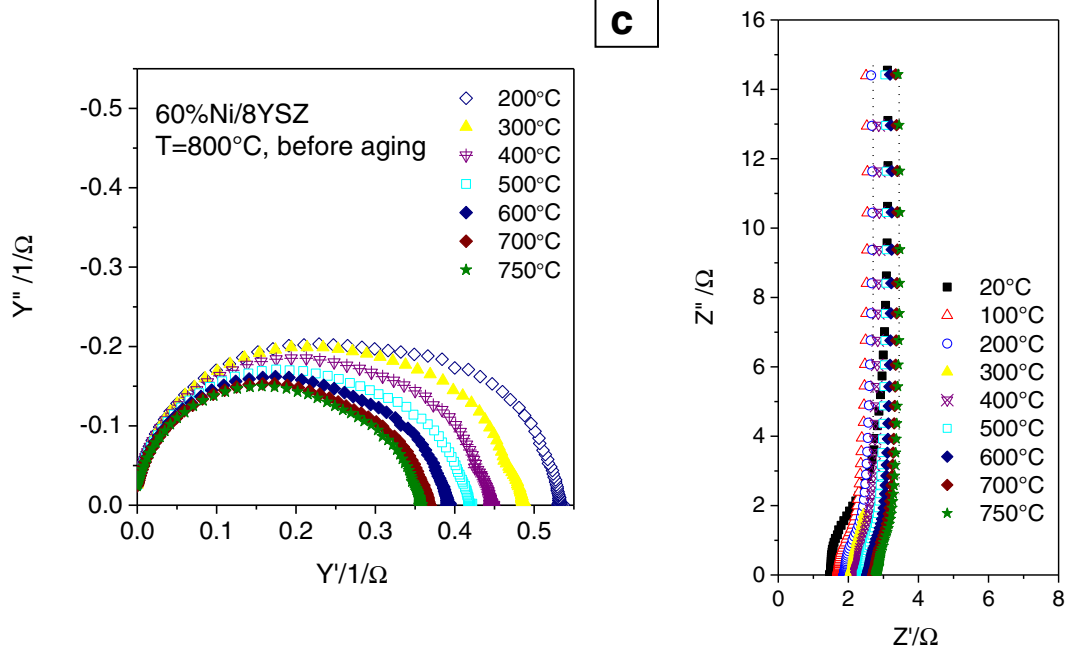

Figure 4 shows dilatometric measurements for samples after aging process. The values of the TEC for all three samples of $\mathrm{Ni} / \mathrm{YSZ}$ materials calculated in the temperature range of $400-700{ }^{\circ} \mathrm{C}$ are almost the same, which suggests no significant dependence of thermal properties of cermets on $\mathrm{Ni}$ content for this temperature 
range. On the other side, these values are an order of magnitude lower than TEC values estimated for the same samples before aging. This is an interesting effect which needs further studies.

\section{Electrical properties}

The effect of aging process on electrical properties of cermet samples was analysed by comparison with respective data measured for initial samples. The impedance spectroscopy measurements showed that all initially prepared cermets $40 \quad \% \quad \mathrm{Ni} / 8 \mathrm{YSZ}, \quad 50 \%$ $\mathrm{Ni} / 8 \mathrm{YSZ}$ and $60 \% \mathrm{Ni} / 8 \mathrm{YSZ}$ samples exhibit an increase in electrical resistance with temperature (Fig. 5).
It is a characteristic behaviour for metallic conductivity. An analysis of impedance spectra revealed that equivalent circuit presented in Fig. 6a represents well the impedance data of basic materials. The elements R1 and L1 correspond to electrode resistance effect (values of R1 nearly do not change with temperature increasing) and inductance of the wires, respectively, whereas R2L2 can be attributed to nickel paths which are responsible for metallic conductivity of cermet (values of R2 raise with temperature increasing). Figure 7 illustrate the Nyquist plots for all initial samples.

The electrical properties of materials after aging tests are various, depending on nickel content (Fig. 8). The classical increase of resistance with temperature can be a

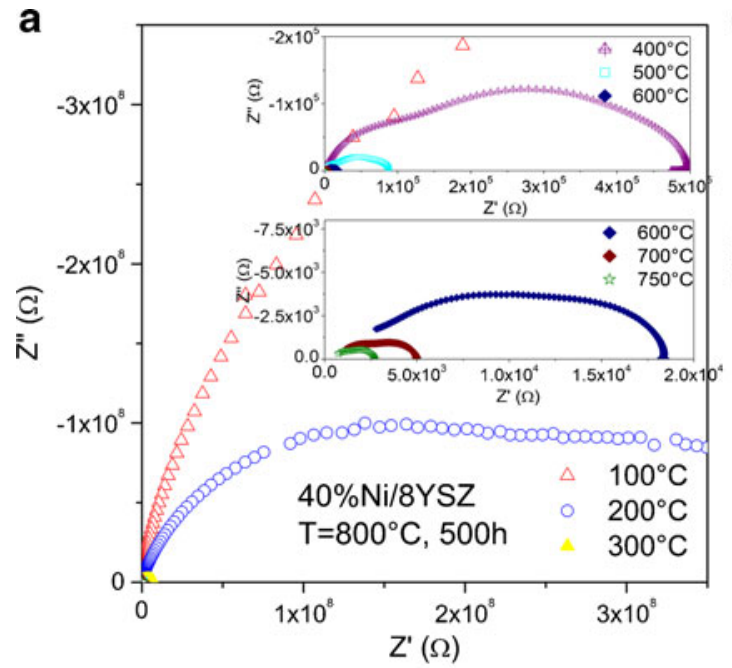

b

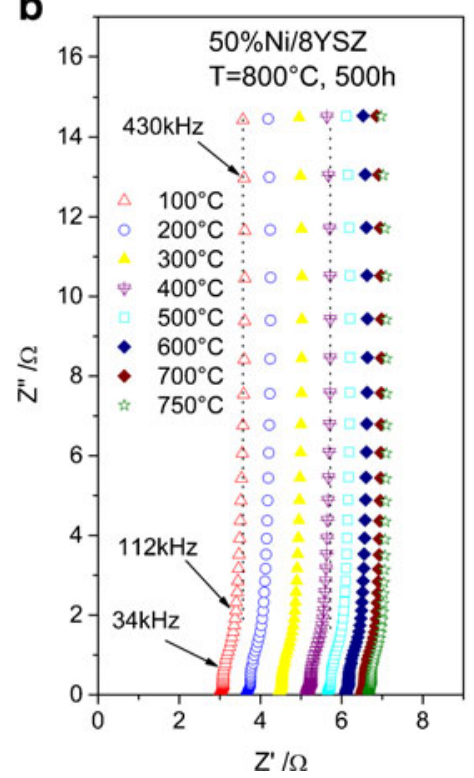

C

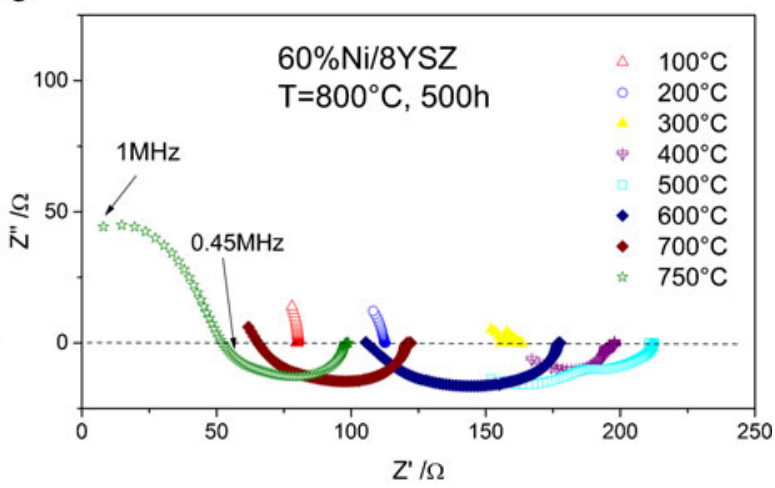

Fig. 8 Nyquist plots for materials after aging: a $40 \% \mathrm{Ni} / \mathrm{YSZ}$, b $50 \% \mathrm{Ni} / \mathrm{YSZ}$, c $60 \% \mathrm{Ni} / \mathrm{YSZ}$. EIS measurements performed in the $10 \% \mathrm{H}_{2} / \mathrm{Ar}$ atmosphere 
observed only for the $50 \% \mathrm{Ni} / 8 \mathrm{YSZ}$ material. It demonstrates that metallic character of conductivity for this material after aging process is retained (Fig. 8b). In contradiction to $50 \%$ Ni/8YSZ material, $40 \%$ $\mathrm{Ni} / 8 \mathrm{YSZ}$ sample behaves like dielectric which shows decreasing of resistivity with temperature growth (it corresponds to ionic conductivity ) (Fig. 8a). Metallic conductivity disappears after aging of initial samples as a result of disconnecting of nickel paths. For $60 \%$ $\mathrm{Ni} / 8 \mathrm{YSZ}$ sample, the Nyquist plots are more complex (Fig. 8c); it can, however, be noticed that the material demonstrates a metallic conductivity component in the range of low temperatures $\left(100-300{ }^{\circ} \mathrm{C}\right)$ and behaves as semiconductor in the higher temperatures, which was identified on the basis of presence of positive values in the points on $Z^{\prime}$ vs. $Z^{\prime \prime}$ plot. Untypical character of impedance spectra for $60 \% \mathrm{Ni} / 8 \mathrm{YSZ}$ is probably connected with agglomeration of nickel particles in a sample with such large content of $\mathrm{Ni}$, but undoubtedly this effect requires further investigations.

The example of parameters determined for spectra (obtained for $50 \% \mathrm{Ni} / \mathrm{YSZ}$ ) is presented in Table 3. The parameters are calculated on the basis of circuits shown in Fig. 6a (for initial sample and for sample after aging during $200 \mathrm{~h}$ ) and Fig. $6 \mathrm{~b}$ (sample after aging during $500 \mathrm{~h}$ ). It can be observed that aging process carried out for 200 and for $500 \mathrm{~h}$ does not have influence on electrical properties of $50 \%$ $\mathrm{Ni} / Y S Z$ cermet. The values of specific resistance $\rho_{2}$ (for initial material and for material after $200 \mathrm{~h}$ of aging) and $\rho$ (for material after $500 \mathrm{~h}$ of aging) are close to each other. The values of resistivity slightly increase with the time of aging (Fig. 9). This is a confirmation that material $50 \% \mathrm{Ni} / \mathrm{YSZ}$ obtained by citric method is the most interesting one due to its thermal stability. At the same time, it is important to remember (even in case of this material) that a long time of aging can lead to deterioration of electrical properties of the anode.

Table 3 Electrical parameters of $50 \% \mathrm{Ni} / \mathrm{YSZ}$ material determined from EIS measurements

\begin{tabular}{|c|c|c|c|c|}
\hline Temperature $\left({ }^{\circ} \mathrm{C}\right)$ & $\rho_{1}(\Omega \mathrm{cm})$ & L1 (H) & $\rho_{2}(\Omega \mathrm{cm})$ & L2 $(\mathrm{H})$ \\
\hline \multicolumn{5}{|l|}{ Initial sample } \\
\hline 200 & $8.88 \pm 0.27$ & $(4.12 \pm 0.05) \times 10^{-6}$ & $0.97 \pm 0.01$ & $(5.84 \pm 0.04) \times 10^{-6}$ \\
\hline 300 & $15.58 \pm 0.49$ & $(5.29 \pm 0.09) \times 10^{-6}$ & $1.01 \pm 0.01$ & $(5.40 \pm 0.03) \times 10^{-6}$ \\
\hline 400 & $15.38 \pm 0.60$ & $(5.31 \pm 0.09) \times 10^{-6}$ & $1.09 \pm 0.01$ & $(5.47 \pm 0.03) \times 10^{-6}$ \\
\hline 500 & $1.79 \pm 0.02$ & $(2.63 \pm 0.01) \times 10^{-6}$ & $2.88 \pm 0.05$ & $(2.44 \pm 0.04) \times 10^{-5}$ \\
\hline 600 & $1.99 \pm 0.02$ & $(2.67 \pm 0.01) \times 10^{-6}$ & $2.87 \pm 0.04$ & $(2.27 \pm 0.03) \times 10^{-5}$ \\
\hline 700 & $4.78 \pm 0.58$ & $(9.17 \pm 0.34) \times 10^{-6}$ & $1.70 \pm 0.07$ & $(7.97 \pm 0.27) \times 10^{-6}$ \\
\hline 750 & $4.40 \pm 0.49$ & $(8.50 \pm 0.29) \times 10^{-6}$ & $1.84 \pm 0.09$ & $(8.42 \pm 0.30) \times 10$ \\
\hline \multicolumn{5}{|c|}{ Sample after aging for $200 \mathrm{~h}$} \\
\hline 20 & $2.17 \pm 0.02$ & $(3.02 \pm 0.67) \times 10^{-6}$ & $1.19 \pm 0.01$ & $(1.05 \pm 0.07) \times 10^{-6}$ \\
\hline 100 & $3.57 \pm 0.04$ & $(3.33 \pm 0.09) \times 10^{-6}$ & $1.21 \pm 0.01$ & $(8.38 \pm 0.04) \times 10^{-6}$ \\
\hline 200 & $4.11 \pm 0.05$ & $(3.38 \pm 0.01) \times 10^{-6}$ & $1.35 \pm 0.01$ & $(8.24 \pm 0.04) \times 10^{-6}$ \\
\hline 300 & $5.60 \pm 0.08$ & $(3.83 \pm 0.01) \times 10^{-6}$ & $1.42 \pm 0.01$ & $(7.39 \pm 0.03) \times 10^{-6}$ \\
\hline 400 & $2.77 \pm 0.03$ & $(2.85 \pm 0.05) \times 10^{-6}$ & $2.33 \pm 0.02$ & $(14.67 \pm 0.12) \times 10^{-6}$ \\
\hline 500 & $2.90 \pm 0.03$ & $(2.84 \pm 0.05) \times 10^{-6}$ & $2.58 \pm 0.02$ & $(15.12 \pm 0.13) \times 10^{-6}$ \\
\hline 600 & $3.07 \pm 0.03$ & $(2.83 \pm 0.04) \times 10^{-6}$ & $2.83 \pm 0.02$ & $(15.56 \pm 0.01) \times 10^{-6}$ \\
\hline \multirow[t]{2}{*}{700} & $3.10 \pm 0.02$ & $(2.77 \pm 0.04) \times 10^{-6}$ & $3.20 \pm 0.03$ & $(17.13 \pm 0.02) \times 10^{-6}$ \\
\hline & $\rho(\Omega \mathrm{cm})$ & & $L(\mathrm{H})$ & \\
\hline \multicolumn{5}{|c|}{ Sample after aging for $500 \mathrm{~h}$} \\
\hline 20 & $1.13 \pm 0.01$ & & $(2.48 \pm 0.02) \times 10^{-6}$ & \\
\hline 100 & $1.44 \pm 0.01$ & & $(2.48 \pm 0.02) \times 10^{-6}$ & \\
\hline 200 & $1.77 \pm 0.01$ & & $(2.46 \pm 0.02) \times 10^{-6}$ & \\
\hline 300 & $2.14 \pm 0.01$ & & $(2.45 \pm 0.02) \times 10^{-6}$ & \\
\hline 400 & $2.48 \pm 0.01$ & & $(2.44 \pm 0.02) \times 10^{-6}$ & \\
\hline 500 & $2.73 \pm 0.01$ & & $(2.43 \pm 0.02) \times 10^{-6}$ & \\
\hline 600 & $2.92 \pm 0.01$ & & $(2.43 \pm 0.02) \times 10^{-6}$ & \\
\hline 700 & $3.12 \pm 0.01$ & & $(2.42 \pm 0.01) \times 10^{-6}$ & \\
\hline
\end{tabular}




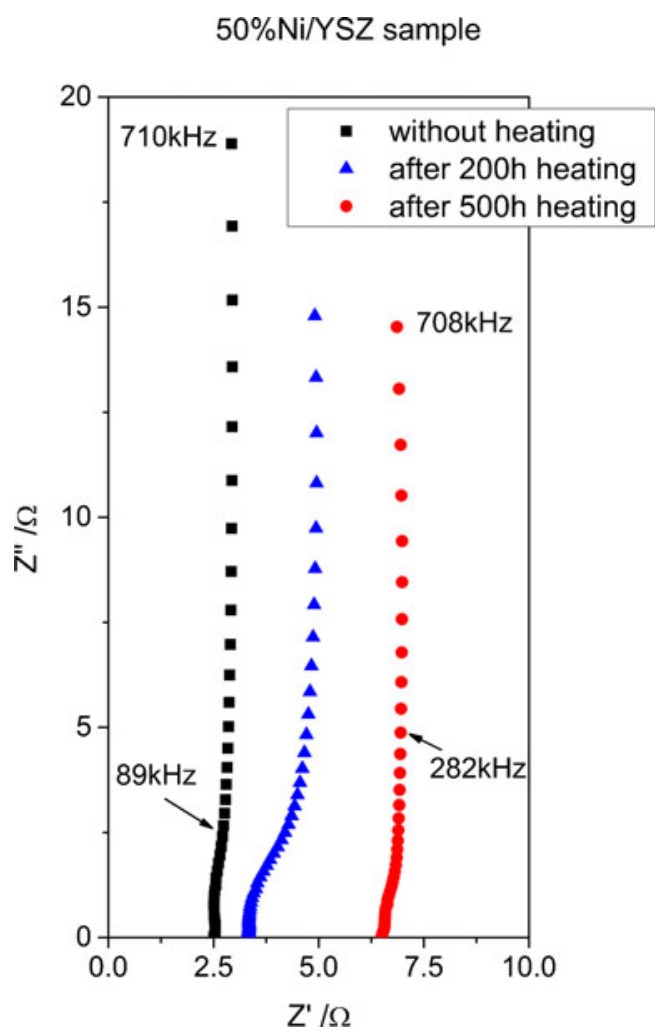

Fig. 9 The comparison of impedance spectra of initial sample, after aging for 200 and for $500 \mathrm{~h}$ for $50 \% \mathrm{Ni} / \mathrm{YSZ}$ material

\section{Sintering tests}

The pellets consisting of initial materials were sintered at various temperatures $(800,1,000,1,200$ and $\left.1,300{ }^{\circ} \mathrm{C}\right)$. The total porosity after sintering was

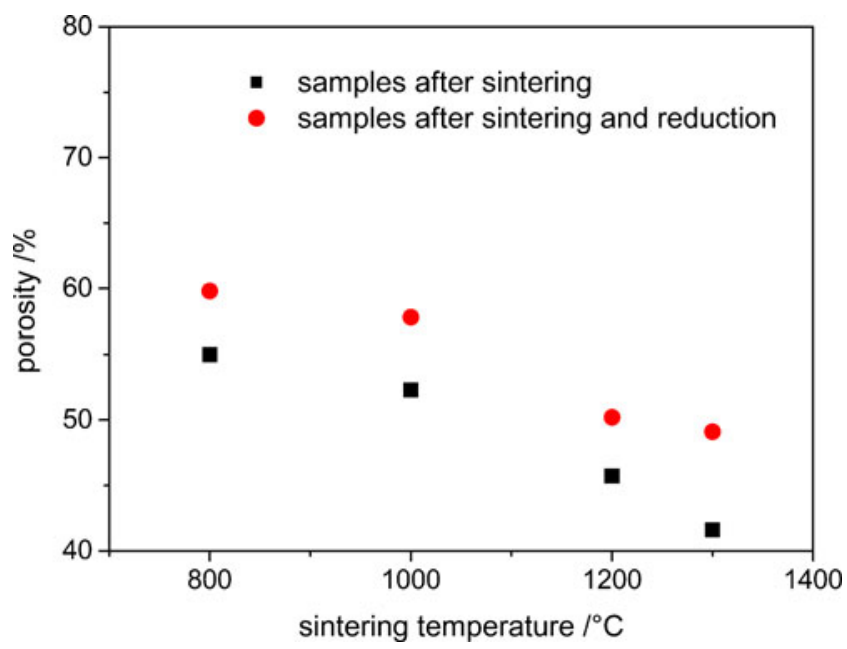

Fig. 10 The total porosity versus sintering temperature on the example $50 \% \mathrm{Ni} / \mathrm{YSZ}$

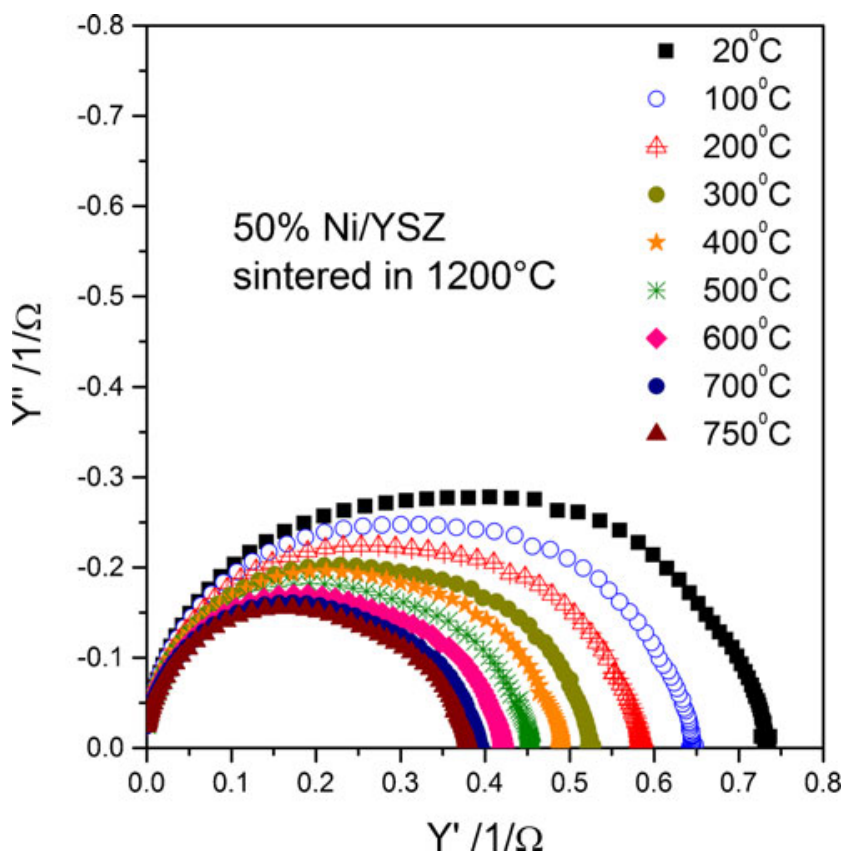

Fig. 11 The example of Nyquist plots for $50 \% \mathrm{Ni} / \mathrm{YSZ}$ sintered in $1,200{ }^{\circ} \mathrm{C}$

estimated. For all the compositions of cermets sintered at $800{ }^{\circ} \mathrm{C}$, porosity values are lower than those in case of initial samples because nickel, which is a component of cermets, undergoes oxidation during heating in air. The values of porosity decreased with increasing temperature which is related to processes of cermet sintering. The porosity increased after reduction of nickel oxide due to the release of steam. An example of porosity versus sintering temperature dependence of $50 \% \mathrm{Ni} / 8 \mathrm{YSZ}$ cermet is shown in Fig. 10. It is very important that even for sample sintered at $1,300{ }^{\circ} \mathrm{C}$, the value of porosity remain close to $50 \%$ since such porosity is suitable for applying this cermet as anode material.

The measurements of electrical properties for all cermets studied, regardless of sintering temperature, revealed metallic conductivity (an example of Nyquist plots for $50 \% \mathrm{Ni} / \mathrm{YSZ}$ sintered in $1,200{ }^{\circ} \mathrm{C}$ is presented in Fig. 11). A comparison of admittance measured for the samples at all sintering temperatures for different nickel content are shown in the Nyquist plots (Fig. 12). All presented curves show semicircles describing electron conductivity (equivalent circuit Fig. 6a). It was observed that metallic conductivity appeared for the all sintering temperatures. Nevertheless, the most important fact is that sintering of materials in the range of $800-1,200^{\circ} \mathrm{C}$ does not change the value of metallic conductivity. Only in the case $40 \% \mathrm{Ni} / \mathrm{YSZ}$ sample sintered at $800{ }^{\circ} \mathrm{C}$, the admittance was twice lower in comparison to other sintering temperatures, and it is likely that an increase of sintering temperature improved contacts between nickel grains in this sample. 
a

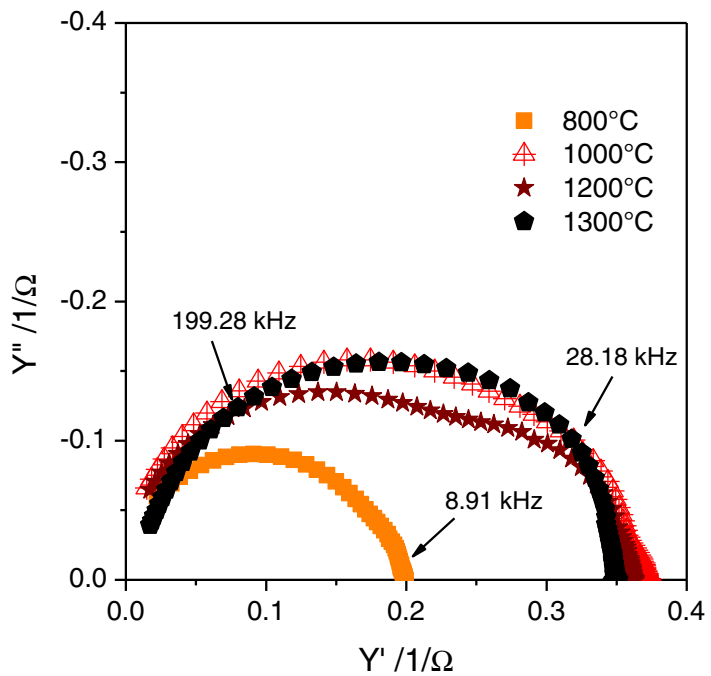

b

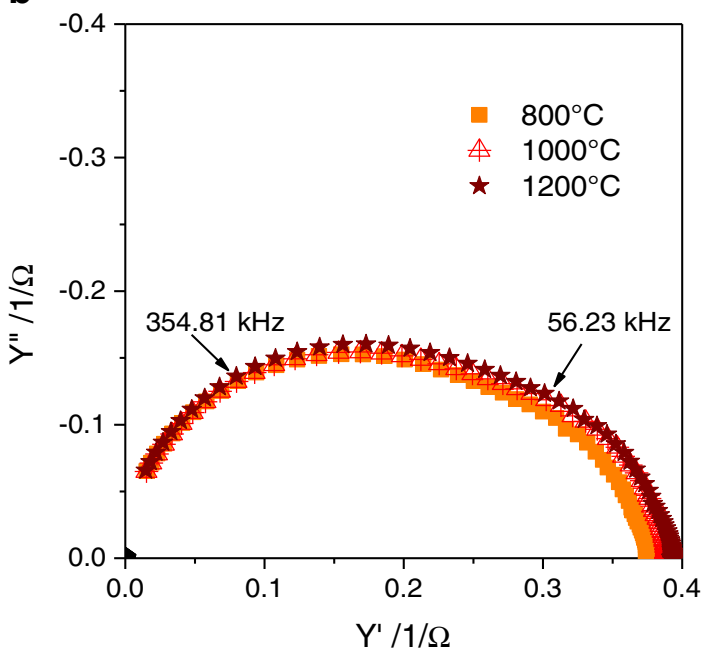

C

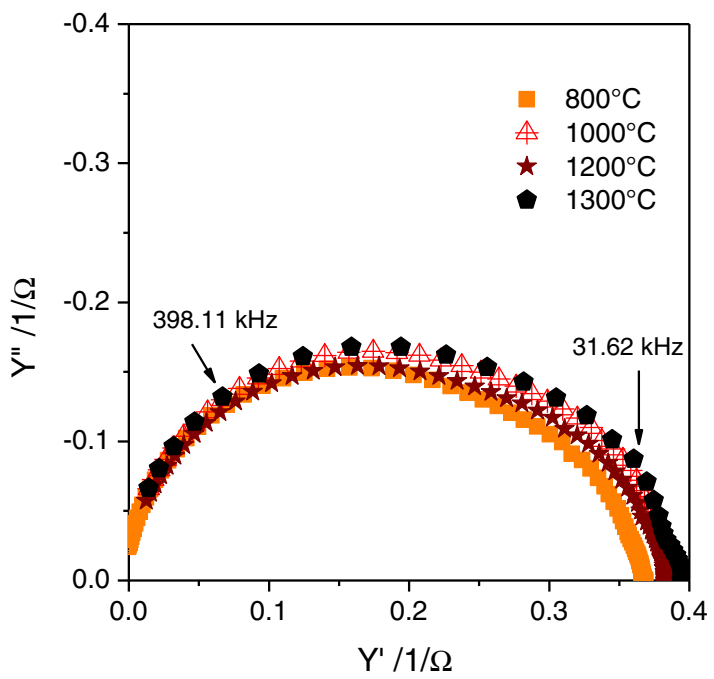

Fig. 12 The comparison of Nyquist plots in $700{ }^{\circ} \mathrm{C}$ for a $40 \% \mathrm{Ni} /$ YSZ, b $50 \% \mathrm{Ni} / \mathrm{YSZ}$ and c $60 \% \mathrm{Ni} / \mathrm{YSZ}$ samples sintered in 800 , $1,000,1,200$ and $1,300{ }^{\circ} \mathrm{C}$

\section{Conclusions}

The citric method is very useful for obtaining nanosize, homogenous materials. Thermal treatment of Ni/YSZ cermet materials in hydrogen leads to reduction of nickel oxide to metallic nickel with simultaneous growth of nickel particles. Reduction also results in decreasing of material's density while increasing its porosity level. The values of porosity for materials obtained by citric method (close to $50 \%$ ), even for materials sintered in $1,300{ }^{\circ} \mathrm{C}$, make these cermets suitable as anode material. TEC values show that all obtained materials reveal thermal compatibility with pure YSZ and all three compositions of Ni/YSZ cermet, initial materials, reveal metallic conductivity.

Aging of materials for $200 \mathrm{~h}$ does not alter their conductivity, but extension of aging time to $500 \mathrm{~h}$ leads to disappearance of metallic conductivity in a $40 \% \mathrm{Ni} / 8 \mathrm{YSZ}$ sample. It is consistent with breaking of nickel paths in this material. After such a long time at hydrogen atmosphere, $50 \% \mathrm{Ni} / 8 \mathrm{YSZ}$ and $60 \% \mathrm{Ni} / 8 \mathrm{YSZ}$ materials retain metallic conductivity. In the case of $60 \% \mathrm{Ni} / 8 \mathrm{YSZ}$, the values of conductivity are at least one order of magnitude lower than those of $50 \% \mathrm{Ni} / 8 \mathrm{YSZ}$. This demonstrates that only in $50 \% \mathrm{Ni} / 8 \mathrm{YSZ}$ sample, material continuity of nickel paths remained unchanged. In $60 \%$ $\mathrm{Ni} / 8 Y S Z$ materials, the nickel probably undergoes agglomeration. The sintering tests show that regardless of sintering temperature (in the range $800-1,200^{\circ} \mathrm{C}$ ), metallic conductivities are almost constant for the same materials.

Open Access This article is distributed under the terms of the Creative Commons Attribution License which permits any use, distribution, and reproduction in any medium, provided the original author(s) and the source are credited.

\section{References}

1. Kim SD, Moon H, Hyun S-H, Moon J, Kim J, Lee H-W (2007) NiYSZ cermet anode fabricated from NiO-YSZ composite powder for high-performance and durability of solid oxide fuel cells. Solid State Ionics 178:1304-1309

2. Park YM, Lee HJ, Bae HY, Ahn JS, Kim H (2012) Effect of anode thickness on impedance response of anode-supported tubular solid oxide fuel cell. Int J Hydrogen Energy 37:4394-4400

3. Lanzini A, Leone P (2010) Experimental investigation of direct internal reforming of biogas in solid oxide fuel cells. Int $\mathrm{J}$ Hydrogen Energy 35:2463-2476

4. Sato K, Okamoto G, Naito M, Abe H (2009) NiO/YSZ nanocomposite particles synthesized via co-precipitation method for electrochemically active Ni/YSZ anode. J Power Sources 193:185-188

5. Priyatham T, Bauri R (2010) Synthesis and characterization of nanocrystalline Ni-YSZ cermet anode for SOFC. Mater Charact 61(1):54-58

6. Marinsek M, Zupan K (2010) Microstructure evaluation of sintered combustion-derived fine powder NiO-YSZ. Ceram Int 36:1075-1082 
7. Kim SD, Moon H, Hyun S-H, Moon J, Kim J, Lee H-W (2006) Performance and durability of Ni-coated YSZ anodes for intermediate temperature solid oxide fuel cells. Solid State Ionics 177:931-938

8. Kakade MB, Ramanathan R, Das D (2011) Gel-combustion, characterization and processing of porous Ni-YSZ cermet for anodes of solid oxide fuel cells (SOFCs). Ceram Int 37:195-200

9. Suciu C, Hoffmann AC, Doroloti E, Tetean R (2008) NiO/YSZ nanoparticles by new sol-gel route. Chem Eng J 140:586-592

10. Shao G-Q, Cai H, Xie J-R, Duan X-L, Wu B-L, Yuan R-Z, Guo JK (2003) Preparation of nanocomposite Ni/YSZ cermet powder by EDTA complex-gel conversion process. Mater Lett 57:3287-3290

11. Laguana-Bercero MA, Larrea A, Merino RI, Pena JI, Orera VM (2005) Stability of channeled Ni-YSZ cermets produced from selfassembled NiO-YSZ directionally solidified eutectics. J Am Ceram Soc 88(11):3215-3217

12. Han KR, Jeong Y, Lee H, Kim C-S (2007) Fabrication of Ni/YSZ anode material for SOFC via mixed $\mathrm{NiO}$ precursors. Mater Lett 61:1242-1245

13. Drożdż-Cieśla E, Wyrwa J, Pyda W, Rękas M (2012) A new method of preparing Ni/YSZ cermet materials. J Mater Sci 47:2807-2817

14. Pratihar SK, Dassharma A, Maiti HS (2005) Processing microstructure property correlation of porous Ni-YSZ cermet anode for SOFC application. Mater Ress Bull 40:1936-1944

15. Clemmer RMC, Corbin SF (2009) The influence of pore and $\mathrm{Ni}$ morphology on the electrical conductivity of porous $\mathrm{Ni} / \mathrm{YSZ}$ composite anodes for use in solid oxide fuel cell applications. Solid State Ionics 180:721-730

16. Radovic M, Lara-Curzio E, Trejo RM, Wang H, Porter WD (2007) Advances in solid oxide fuel cells II. Wiley, Hoboken, pp 79-85

17. Primdahl S, Mogensen M (2000) Durability and thermal cycling of $\mathrm{Ni} /$ YSZ cermet anodes for solid oxide fuel cell. J Appl Electrochem 30:247-257

18. Baek S-W, Bae J (2011) Anodic behavior of $8 \mathrm{Y}_{2} \mathrm{O}_{3}-\mathrm{ZrO}_{2} / \mathrm{NiO}$ cermet using an anode-supported electrode. Int $\mathrm{J}$ Hydrogen Energy 36:689-705

19. Ettler M, Timmermann H, Malzbender J, Weber A, Menzler NH (2010) Durability of Ni anodes during reoxidation cycles. J Power Sources 195:5452-5467

20. Talebi T, Sarrafi MH, Haji M, Raissi B, Maghsoudipour A (2010) Investigation on microstructures of NiO-YSZ composite and NiYSZ cermet for SOFCs. Int J Hydrogen Energy 35:9440-9447

21. Laurencin J, Delette G, Morel B, Lefebvre-Joud F, Dupeux M (2009) Solid oxide fuel cells damage mechanisms due to Ni-YSZ re-oxidation: case of the anode supported cell. J Power Sources 192:344-352

22. Hattori M, Takeda Y, Sakaki Y, Nakanishi A, Ohara S, Mukai K, Lee J-H, Fukui T (2004) Effect of aging on conductivity of yttria stabilized zirconia. J Power Sources 126:23-27

23. Krikorian OH (1960) UCRL-6132

24. Männer R, Ivers-Tiffée E, Wersing W (1991) In Grosz F, Zegers P, Singhal SC, Yamamoto O (eds) SOFC II. Commission of the European Communities, Luxemburg, L. EUR-13564-EN. 715 